\title{
KEBIJAKAN HUKUM PIDANA DALAM PERTANGGUNGJAWABAN TINDAK PIDANA KORPORASI DI INDONESIA
}

Oleh :

\author{
I Dewa Made Suartha ${ }^{1}$
}

\begin{abstract}
The acceptance of corporation as the subject of criminal act brings problem to criminal law policy in corporation criminal act responsibility. There are 2 principle problems in this study : (1) How is the current criminal law policy in corporation criminal act responsibility?. (2) How is criminal law policy upon the corporation criminal act responsibility in iusconstituendum perspective? The research used normative law method with legislation, comparative and law concept analysis approaches. The result of the research : (1) Criminal code has not regulates corporation as the subject of criminal act that is accountable for criminal law, nevertheless it is partial but inconsistent, (2) Criminal Code Bill 1999-2000 has clearly and completely regulated corporation as subject of criminal act and is accountable for criminal law and accept unconditional criminal responsibility as well as substitute criminal responsibility, although with the exception to solve difficult problem in order to prove mistakes made by corporation.
\end{abstract}

\section{Keywords: Policy corporation law, Criminal act,responsibility}

\begin{abstract}
Abstrak
Diterimanya korporasi sebagai subjek tindak pidana, dapat menimbulkan permasalahan kebijakan hukum pidana dalam pertanggungjawaban tindak pidana korporasi. Dalam penelitian ini terdapat dua permasalahan pokok, yaitu (1) Bagaimanakah kebijakan hukum pidana pada saat ini dalam pertanggungjawaban tindak pidana korporasi?. (2) Bagaimanakah kebijakan hukum pidana terhadap pertanggungjawaban tindak pidana korporasi dalam perspektif iusconstituendum ?Metode penelitian yang dipergunakan adalah metode penelitian hukum normatif dengan pendekatan perundang-undangan, perbandingan dan analisis konsep hukum. Hasil penelitian adalah : (1) KUHP tidak mengatur korporasi sebagai subjek tindak pidana yang dapat dipertanggungjawabkan dalam hukum pidana sedangkan di beberapa perundang-undangan di luar KUHP telah mengatur korporasi sebagai subjek tindak pidana yang dapat dipertanggungjawabkan dalam hukum pidana, namun masih bersifat parsial dan tidak konsisten, (2) Rancangan KUHP 2014-2015 telah mengatur secara lengkap dan tegas korporasi sebagai subjek tindak pidana dan dapat dipertanggungjawabkan dalam hukum pidana dan menerima pertanggungjawaban pidana mutlak serta pertanggungjawaban

1 Penulis adalah Dosen Fakultas Hukum Universitas Udayana, Denpasar, Bali. Alamat Jalan Drupadi XVII Dewi Uma I No.11 Denpasar, email: dewa_suartha@yahoo.com, dewamarta9@gmail.com
\end{abstract}


pidana pengganti, meskipun dengan pengecualian untuk memecahkan persoalan kesulitan dalam membuktikan adanya unsur kesalahan yang dilakukan oleh korporasi.

\section{Kata kunci : kebijakan hukum korporasi, tindak pidana, pertanggungjawaban}

\section{PENDAHULUAN}

Suatu kenyataan di masyarakat peranan korporasi dalam aktivitas ekonomi sudah tidak di pertanyakan lagi. Sejalan dengan dinamika ekonomi, sepak terjang korporasi yang saat ini lazim dikenal dengan sebutan perusahaan-perusahaan multi nasional (multinational corporation), pada awal tahun 1960 mulai menjadi perhatian para ahli sosial ekonomi. Fenomena dan sepak terjang korporasi itu telah berlangsung sebelum perang dunia ke-2, namun studi yang sistematis dan mendalam baru dimulai pada awal tahun itu. Sementara itu dikalangan kriminologi, studi kritis terhadap peranan korporasi sudah dimulai sejak tahun 1939, melalui suatu pidato bersejarah Edwin $\mathrm{H}$ Suterland di depan "The American Sociological Association". Ia mengemukakan konsep "White Collar Crime" (WCC) yang didefinisikan sebagai " a crime committed by a person of respectability and high social status in the course of his accuption ". 2

Penelitian Suterland yang menggunakan catatan-catatan jawatanjawatan pengaturan (regulatory

2 Shofie, Yusuf, 2002, Pelaku Usaha dan Tindak Pidana Korporasi, Chalia Indonesia, Jakarta, hlm.20 agencies), pengadilan-pengadilan dan komisi-komisi, menemukan bahwa 70 korporasi industri dan perdagangan yang di telitinya masingmasing setidak-tidaknya melakukan satu pelanggaran hukum dan memuat kebijakan-kebijakan yang melanggar hukum.Seperti periklanan yang menyesatkan (false advertising) penyalahgunaan paten (patent abuse), pelanggaran persaingan dagang (wartime trade violation), penetapan harga (pricefitsing), penipuan (fraud) dan penjarahan barang-barang cacat (sale of faulti goods).Di satu sisi peranan korporasi menggerakkan roda perekonomian di suatu negara bahkan melintasi batas-batas Negara, sedangkan pada sisi lainnya disadari atau tidak menimbulkan distorsidistorsi dan ketidakadilan bagi masyarakat.namun hampir tidak dirasakan. ${ }^{3}$

Sejalan dengan hal itu, kongres Perserikatan Bangsa-Bangsa (PBB) ke-5tentang pencegahan kejahatan dan pembinaan pelanggar hukum (On the prevention of crime and the treatment of offenders) bulan September tahun 1975 di Jenewa,

3 Remy Sjahdeini, Sutan, 2006, Pertanggungjawaban Pidana Korporasi, PT Grafiti Pers, Jakarta, hlm.2. 
memberikan rekomendasi dengan memperluas pengertian kejahatan terhadap tindakan penyalahgunaan kekuasaan ekonomi secara melawan hukum (illegal abuses of economic power) seperti pelanggaran terhadap konsumen, penyelewengan di bidang pemasaran, peraturan perpajakan, perburuhan, pencemaran lingkungan dan perdagangan oleh perusahaan internasional. Kemudian dalamkongres ke-7 PBB tahun 1985 telah diulangi kembali adanya dimensi baru kejahatan dalam konteks pembangunan. Telah diperingatkan adanya perilaku melanggar hukum pidana yang dilakukan oleh perusahaan-perusahaan yang mempunyai dampak yang sangat negative pada perekonomian Negara. ${ }^{4}$

Perhatian

masyarakat

internasional terhadap kejahatan korporasi secara jelas nampak pula dari usaha dunia internasional untuk menangkal prilaku negatif dari perusahaan-perusahaan multi nasional (multi national enterprise). Usaha tersebut merupakan hasil kerja sama internasional dalam bentuk code conduct of transnasional corporation (UN, Ecosoe, 1997) yang antara lain mengatur : (1) Activities of transnasional corporation (TNC), (2) Treatment of TNC dan Intergovermental co-operation. ${ }^{5}$

4 Reksodiputro, Mardjono, 1994, Kemajuan Pembangunan Ekonomi dan Kejahatan, Pusat Pelayanan Keadilan dan Pengabdian Hukum Universitas Indonesia, Jakarta, hlm.69

5 Muladi, 1995, Korban Kejahatan Korporasi, Bahan Penataran Nasional Hukum Pidana dan Kriminologi, Fakultas Hukum UNDIP, 3-15 Desember, hlm.6
Di Indonesia kebijakan hukum pidana dalam pertanggungjawaban pidana terhadap korporasi harus dilihat melalui kitab UndangUndang hukum pidana (KUHP) dan peraturan perundang-undangan di luar KUHP.Kenyataannya bahwa pertanggungjawaban pidana terhadap tindak pidana korporasi sebagai subjek hukum tidak diatur dalam KUHP secara tegas, mengingat hukum pidana Nasional didesain untuk menghadapi prilaku individu manusia (natuurlijkpersoon).KUHP berdasarkan pada asasnya bahwa hanya manusia yang dapat dituntut sebagai pembuat/pelaku (dader) yang dipertanggungjawabkan dari suatu delik, baik yang berupa kejahatan maupun pelanggaran.

Berdasarkanuraianlatarbelakang diatas, maka dapatlah dirumuskan permasalahan sebagai berikut:

1. Bagaimanakah kebijakan hukum pidana pada saat ini dalam pengaturan pertanggungjawaban tindak pidana korporasi di Indonesia?.

2. Bagaimanakah kebijakan hukum pidana terhadap pengaturan pertanggungjawaban tindak pidana korporasi dalam perspektif iuscostituendum di Indonesia?

Tujuan penulisan ini di samping untuk mengetahui dan menganalisis secara mendalam mengenai kebijakan hukum pidana pada saat ini dalam pengaturan pertanggungjawaban 
tindak pidana korporasi pada umumnya, juga secara khusus kebijakan hukum pidana terhadap pengaturanpertanggungjawabantindak pidana korporasi dalam perspektif iusconstituendumdi Indonesia.

\section{METODE PENELITIAN}

Jenis penelitian yang dipergunakan termasuk ke dalam penelitian hukum normatif yaitu penelitian hukum yang dilakukan dengan cara meneliti bahan pustaka yakni mempelajari dan mengkaji asasasas hukum dan kaedah-kaedah hukum positif yang berasal dari kepustakaan dan peraturan perundang-undangan. Adapun pendekatan masalah yang dipergunakan yaitu pendekatan perundang-undangan (statute approach), pendekatan perbandingan (comparative approach), dan pendekatan analisis konsep hukum (analytical and conceptual approach). Bahan penelitian yang dipergunakan meliputi baik bahan hukum primer, bahan hukum sekunder maupun bahan hukum tersier. Teknik pengumpulan bahan hukum dengan studi dokumen, menggunakan system kartu yaitu disusun berdasarkan abjad yang diisi catatan sesuai dengan permasalahan yang akan dipecahkan. Kemudian dianalisis dengan menggunakan alur logika dalam penelitian hukum normative, yakni secara sistematis mendeskripsikan bahan hukum yang meliputi isi dan struktur, dalam sistematisasi hukum positif. Kemudian dari analisis tersebut secara umum/ deduktif akanditarik kesimpulan secara induktif.

\section{HASIL DAN PEMBAHASAN}

3.1. Kebijakan Hukum Pidana dan Pertanggungjawaban Tindak Piidana Korporasi Dalam IusConstitutum.

\section{1.a. Pengaturan dalam KUHP}

Di Dalam Kitab Undang-Undang Hukum Pidana (KUHP) sebagai pelembagaan reaksi sosial formal negara terhadap tindak pidana atau kejahatan tidak mengatur korporasi sebagai subjek hukum yang dapat dipertanggungjawabkan dalam hukum pidana, mengingat hukum pidana kita didesain untuk menghadapi perilaku individumanusia (natuurlijkepersoon). KUHP berlandaskan pada asasnya bahwa hanya manusia yang dapat dituntut sebagai pembuat atau pelaku (dader) dari suatu delik, baik yang berupakejahatan,maupun pelanggaran. Hal tersebut dapat dilihat dari prinsipprinsipnya antara lain :

1. Cara perumusan delik yang selalu dimulai dengan kata "barang siapa ..." yang secara umum dimaksudkan atau mengacu kepada orang atau manusia.

2. Sistem pidana yang dianut, khususnya pidana hilang kemerdekaan yang hanya dapat dijatuhkan kepada manusia dan tidak mungkin dapat dijatuhkan kepada badan hukum. 
3. Menurut asas-asas hukum pidana Indonesia badan hukum tidak dapat mewujudkan delik. Hoofgerechtshof van N.I.dahulu dalam aresnya tanggal 5 Agustus 1925 menegaskannya dengan alasan, bahwa hukum pidana Indonesia dibentuk berdasarkan ajaran kesalahan individual. Sistem hukum pidana Indonesia tidak memungkinkan penjatuhan pidana denda kepada korporasi, oleh karena pihak yang dijatuhi pidana denda diberikan pilihan untuk menggantikannya dengan pidana kurungan pengganti denda (Lihat Pasal 30 ayat (1), (2), (3), dan (4) KUHP).

4. Tidak ada prosedur khusus dalam hukum acara pidana untuk korporasi. $^{6}$

\section{2.b. Pengaturan dalam Perundang- Undangan di luar KUHP}

Sebagai upaya untuk mengetahui pengaturan pertanggungjawaban tindak pidana korporasi dalam peraturan perundang-undangan di Indonesia, ternyata korporasi dapat melakukan suatu tindak pidana dalam perkembangannya diatur dalam perundang-undangan di luar KUHP sudah dikenal sejak tahun 1951, yakni UU No.1 Tahun 1951 tentang Pernyataan berlakunya UU No.12 Tahun 1948 tentang Tenaga Kerja

6 Suartha, I Dewa Made, 2015, Hukum Pidana Korporasi Persfektif Pertanggungjawaban Pidana dalam Kebijakan Hukum Pidana Indonesia, Setara Press, Malang, hlm.46-47. untuk seluruh Indonesia dan mulai dikenal secara luas pada tahun 1955, yaitu dengan dikeluarkannya UU No. 7 Drt Tahun 1955 tentang Pengusutan, Penuntutan, dan Peradilan Tindak Pidana Ekonomi.

Beberapa peraturan perundangundangan yang menjadikan korporasi sebagai subjek hukum pidana, adalah: a. UU No.22 Tahun 1957 no UU No.26 Tahun 1957 tentang Penyelesaian Perburuhan (Pasal 27);

b. UU No.3 Tahun 1958 tentang Penempatan Tenaga Asing (Pasal 13);

c. UU No.38 Tahun 1960 tentang Penetapan Luas Tanah Untuk Tanaman Tertentu (Pasal 4);

d. UU No.32 Tahun 64 tentang Peraturan Lalulintas Devisa (Pasal 25);

e. UU No.2 Tahun 1981 tentang Metrologi Legal (Pasal 34);

f. UU No.7 Tahun 1981 tentang Wajib Lapor Ketenagakerjaan di Perusahaan (Pasal 11);

g. UU No.3 Tahun 1982 tentang Wajib Daftar Perusahaan (Pasal $35)$;

h. UU No.14 Tahun 1984 tentang Wabah Penyakit Menular (Pasal 15);

i. UU No.7 Tahun 1992 tentang jo UU No.10 Tahun 1998 tentang Perbankan (Pasal 46);

j. UU No.23 Tahun 1997 tentang Pengelolaan Lingkungan Hidup (Pasal 45 dan 46); 
k. UU No.5 Tahun 1997 tentang Psikotropika (Pasal 70);

1. UU No.22 Tahun 1997 tentang Narkotika (Pasal 80);

m. UU No.5 Tahun 1999 tentang Larangan Praktik Monopoli dan Persaingan Usaha Tidak Sehat (Pasal 1 butir 5);

n. UU No.8 Tahun 1999 tentang Perlindungan Konsumen (Pasal 61);

o. UU No.31 Tahun 1999 jo UU No.20 Tahun 2001 tentang Pemberantasan Tindak Pidana Korupsi (Pasal 20);

p. UU No.36 Tahun 1999 tentang Telekomunikasi (Pasal 15 );

q. UU No.15 Tahun 2002 tentang Tindak Pidana Pencucian Uang (Pasal 1, 4, dan 5);

r. PERPU No.1 Tahun 2002 jo UU No.2 Tahun 2002 no UU No.15 dan 16 Tahun 2003 tentang Tindak Pidana Terorisme.

Bertolak dari beberapa peraturan perundang-undangan tersebut diatas, tampaknya ada keinginan untuk menempatkan korporasi sebagai pelaku tindak pidana, tetapi mengenai pertanggungjawabannya tidak jelas arah perkembangannya. Jika diklasifikasikan, maka akan tampak ada beberapa cara pembuat undang-undang dalam merumuskan kedudukan korporasi sebagai pelaku dan pertanggungjawabannya sebagai berikut:

1) Hanya pengurus sebagai pelaku dan pengurus lah yang bertanggungjawab. Dalam hal ini pengurus korporasi dibebankan kewajiban-kewajiban tertentu yang sebenarnya adalah kewajiban korporasi. (Seperti: Pasal 169, 398, dan 399 KUHP).

2) Korporasi diakui dapat melakukan tindak pidana, tetapi pertanggungjawaban pidananya dibebankan kepada pengurus. Dalam hal ini, beban tanggung jawab pidana dan pengurus seakan-akan hanya sebagai konsekuensi dari suatu jabatan yang telah ditetapkan oleh peraturan intern korporasi. Jadi sama sekali tidak diisyaratkan bahwa pengurus tersebut harus sebagai pemberi perintah atau pemimpin di dalam perbuatan tersebut. Dengan demikian "asas tiada pidana tanpa kesalahan"yang merupakan dasar dari adanya atau tidak adanya pertanggungjawaban pidana telah dikecualikan. (Seperti: Pasal 35 UU No.3 Tahun 1982 tentang Wajib Daftar Perusahaan).

3) Korporasi secara tegas diakui dapat menjadi pelaku tindak pidana dan dapat dipertanggungjawabkan dalam hukum pidana. (Seperti: Pasal 15 UU No.7 Drt Tahun 1955 tentang Pengusutan, Penuntutan, dan Peradilan Tindak Pidana Ekonomi; dan Pasal 20 UU No.31 
Tahun 1999 no UU No.20 Tahun 2001 tentang Pemberantasan Tindak Pidana Korupsi).

Kalau ada ketentuan yang menyatakan bahwa korporasi dapat melakukan tindak pidana dan dapat dituntut serta dapat dijatuhi pidana, maka harus ditentukan kriteria-kriteria/ ukuran-ukuran tentang beberapa hal, diantaranya:

a) Kapankah korporasi dapat dikatakan melakukan tindak pidana. Misalnya Pasal 20 ayat (2) UU No.31 Tahun 1999 no UU No.20 Tahun 2001.

b) Perbuatan yang manakah yang dapat dikategorikan sebagai perbuatan korporasi. Suatu perbuatandapatdikatakansebagai perbuatan korporasi apabila perbuatan tersebut dilakukan dalam rangka mewujudkan tujuan-tujuan korporasi, baik itu dengan sengaja maupun dengan kelalaian.

Dalam mengidentifikasi perbuatan korporasi yang akan dinyatakan sebagai perbuatan yang dilarang dalam hukum pidana, Sherman, Lawrence W., (dikutip oleh: Hamzah Hatrik) menyatakan sebagai berikut:" It is important to distinguish deviance commited by organization from deviance commited in organization. Deviencecommited by an organization is collective rulebreaking action that does not helps achiever organization is individual or collective rule breaking action that does not helps to exploitation of secretaries, for example is a deviant action commited in contex of organization power hierarchies, but it neither benefits nor directly harms to goals of most organization". '

c) Siapakah yang dapat dipertanggungjawabkan dalam hal tindak pidana dilakukan oleh korporasi. Dari beberapa perumusan perundang-undangan yang telah diuraikan diatas, jika suatu korporasi melakukan tindak pidana yang dapat dipertanggungjawabkan adalah:

1) Badan Hukum, perseroan, perserikatan atau yayasan, atau

2) Mereka yang memberikan perintah atau yang bertindak sebagai pemimpin dalam perbuatan atau kelalaian itu, atau

3) Kedua-duanya (1dan 2). Ketentuan tersebut dapat dijumpai, misalnya: Pasal 15 ayat (1) UU No.7 Drt Tahun 1955 tentang Tindak Pidana Ekonomi; Pasal 59 ayat (3) UU No.5 Tahun 1997 tentang Psikotropika; dan Pasal 20 ayat (1) UU No.31 Tahun 1999 no UU No. 20 Tahun 2001 tentang Tindak Pidana Korupsi,

7 Hatrik, Hamzah, 1996, Asas-Asas Pertanggungjawaban Korporasi Dalam Hukum Pidana Indonesia, Rajawali Pers, Jakarta, hlm.108 
misalnya menyatakan:"Jika tindak pidana korupsi dilakukan oleh atau atas nama suatu korporasi, maka tuntutan dan penjatuhan pidana dapat dilakukan terhadap korporasi dan atau pengurusnya".

4) Jenis sanksi yang dapat dijatuhkan terhadap korporasi.

Misalnya: Pasal 46 ayat (1) tentang Narkotika; adalah: "pidana serta tindakan tata tertib"juga diancamkan kepada badan hukum. Jika Indonesia belum menetapkan pemidanaan terhadap korporasi dalam KUHP (W.v.S.) yang berlaku pada saat ini, maka di Nederland dengan Undang-undang (Wet) tanggal 23 Juni 1976 (Staatblad 377) ketentuan tentang pemidanaan korporasi dimasukan ke dalam Wetboek van Strafrecht (W.v.S.) dan melalui artikel 91 W.v.S. ketentuan tersebut berlaku juga terhadap undang-undang lain. Jenis pidana yang dapat dijatuhkan kepada korporasi adalah sebagai berikut:

a. Pengumuman keputusan pengadilan;

b. Pernyataan perampasan alat-alat atau benda tertentu;

c. Maksimum denda uang 10.000 gulden untuk pembuat pelanggaran, dan maksimum denda uang 1.000.000. gulden untuk pembuat kejahatan; d. Pernyataan pembatalan kedudukan badan hukum untuk masa tertentu atau untuk selama-lamanya;

e. Pembubaran.

Semua jenis pidana tersebut dapat dijatuhkan bersama-sama, terkecuali pidana tersebut pada sub $b$ dan e. ${ }^{8}$

Meskipun beberapa peraturan perundang-undangan di luar KUHP telah menerima korporasi sebagai subjek hukum pidana, namun hapir tidak ada yurisprudensi tentang hal itu. Hal ini menurut penulis, karena adanya ketidak jelasan perumusan perundangundangan mengenai beberapa hal, diantaranya:

1. Ketidakjelasan perumusan mengenai kapan suatu korporasi dinyatakan sebagai pelaku dan kapan suatu tindak pidana telah dilakukan atas nama suatu korporasi.

2. Ketidakjelasan perumusan mengenai perbuatan yang akandipertanggungjawabkan melalui perumusan korporasi sebagai subjek tindak pidana.

3. Ketidakjelasan mengenai kriteria apa yang digunakan sebagai pedoman untuk mempertanggungjawabkan korporasi.

4. Masalah pidana yang dijatuhkan terhadap korporasi.

8 Suartha, I Dewa Made, Op.cit., hlm.74 


\subsection{Kebijakan Hukum Pidana Terhadap Tindak Pidana Korporasi Dalam Perspektif IusConstituendum}

2.2.a. Pengaturan Dalam Rancangan KUHP 2014-2015

Dalam ruang lingkup pembentukan KUHP Nasional Indonesia, muncul perhatian khusus mengenai perlindungan sosial terhadap aktivitas korporasi yang bersifat merugikan masyarakat sehingga korporasi dipandang perlu untuk dirumuskan sebagai pelaku dan yang bertanggungjawab.

Konsep korporasi dan pertanggungjawaban korporasi sebagai subjek tindak pidana dirumuskan oleh tim penyusun Naskah Rancangan KUHP 2014-2015 Pasal 162 dan Pasal 44 sampai dengan Pasal 49. Bunyi rumusan pasal-pasal tersebut adalah sebagai berikut :

Pasal 162: korporasi adalah kumpulan terorganisir dari orang dan atau kekayaan, baik merupakan badan hukum ataupun bukan.

Pasal 44 : korporasi dipertanggungjawabkan dapat melakukan tindak pidana.

Pasal 45 : jika dalam pidana dilakukan oleh atau untuk korporasi, penjatuhan pidananya dapat dilakukan terhadap korporasi dan atau pengurusnya.

Pasal 46 : korporasi tidak dapat dipertanggungjawabkan secara pidana terhadap suatu perbuatan yang dilakukan untuk dan atau atas namakorporasi, apabila perbuatan tersebut tidak termasuk dalam lingkup usahanya sebagaimana ditentukan dalam anggaran dasar atau ketentuan lain yang berlaku bagi korporasi yang bersangkutan.

Pasal 47 :pertanggungjawaban pidana pengurus korporasi dibatasi sepanjang pengurus mempunyai kedudukan fungsional dalam struktur organisasi korporasi.

Pasal 48 ayat (1) : dalam mempertimbangkan suatu tuntutan pidana, harus dipertimbangkan apakah bagian hukum lain telah memberikan perlindungan yang lebih berguna daripada menjatuhkan pidana terhadap suatu korporasi;

Ayat (2) :pertimbangan sebagaimana dimaksud dalam ayat (1) harus dinyatakan dalam putusan hakim

Pasal 49 : alasan pemaaf atau alasan pembenar yang dapat diajukan oleh pembuat yang bertindak untuk dan atas nama korporasi, dapat diajukan oleh korporasi sepanjang alasan tersebut langsung berhubungan dengan perbuatan yang didakwakan pada korporasi.

Mengenai kedudukan sebagai pelaku dan sifat pertanggungjawaban korporasi disebutkan dalam penjelasan Pasal 46 Rancangan KUHP 2014-2015 sebagai berikut :

a. penguruskoperasi sebagai pelaku dan oleh karena itu pengurus lah yang bertanggungjawab;

b. korporasi sebagai pembuat dan pengurus yang bertanggungjawab; 
c. korporasi sebagai pembuat dan juga sebagai yang bertanggungjawab.

Oleh karena itu jika suatu tindak pidana dilakukan oleh dan untuk suatu korporasi, maka penuntutan nya dapat dilakukan dan pidananya dapat dijatuhkan terhadap korporasi sendiri, atau koperasi dan pengurusnya atau pengurusnya saja.

Pidana pokok yang dapat dijatuhkan pada korporasi menurut Rancangan KUHP 2014-2015 hanyalah "pidana denda" dengan ancaman maksimum pidana denda lebih berat dibandingkan dengan ancaman pidana denda terhadap orang, yaitu kategori lebih tinggi berikutnya. Pidana denda paling banyak untuk korporasi adalah yang melakukan tindak pidana yang diancam pidana penjara paling lama 7 tahun sampai dengan 15 tahun adalah denda kategori $\mathrm{V}$ dan pidana mati, pidana penjara seumur hidup, atau pidana penjara paling lama 20 tahun adalah denda kategori VI. Sedangkan pidana denda paling sedikit untuk korporasi adalah denda kategori IV (Pasal 75 ayat (4), (5), (6)).Pidana tambahan yang dapat dijatuhkan terhadap korporasi berupa pencabutan hak yang diperoleh korporasi (Pasal 84 ayat (2).

\section{2.b. Relevansi Penerimaan Pertanggungjawaban Pidana Korporasi Dalam Hukum Pidana.}

Dalam hukum pidana konsep liability atau pertanggungjawaban merupakan konsep sentral yang dikenal dengan ajaran kesalahan. Dalam bahasa latin ajaran kesalahan ini dikenal dengan sebutan"mensrea". Doktrin mensrea itu dilandaskan pada maxim"actis non facitreum nisi mens sit rea", yaitu "suatu perbuatan tidak mengakibatkan seseorang bersalah keaculi jika pikiran orang itu jahat". Dalam hukum pidana inggris doktrin tersebut dirumuskan dengan"an act does not make a person guilty, unless the mind is legality blameworthy".

Berdasarkan asas tersebut, maka ada dua syarat yang harus dipenuhi untuk dapat memidana seseorang, yaitu: (1) ada perbuatan lahiriah yang terlarang (actusreus), dan (2) ada sikap bathin jahat/tercela lahiriah yang terlarang. Pertanggungjawaban pidana itu selalu berhubungan dengan kesalahan, baik dalam bentuk kesengajaan maupun kealpaan.

Hukum pidana Indonesia pada dasarnya menganut asas kesalahan. Ketentuan tersebut dapat dilihat dalam Pasal 6 ayat (2) dan Pasal 8 tentang Kekuasaan Kehakiman, Pasal 183, Pasal 193 ayat(1), danPasal 197 ayat(1) tentang Kitab Undang-Undang Hukum Acara Pidana (KUHAP) dan di dalam KUHP, walaupun tidak disebutkan secara eksplisit, tetapi dari rumusan pasal-pasalnya mengindikasikan dianut nya asas kesalahan, baik dalam bentuk kesengajaan maupun kealpaan. Disamping itu juga dalam hukum pidana dikenal suatu asas yang 
tidak tertulis yang berbunyi:"'geenst rafzonderschuld"(tiada pidana tanpa kesalahan).

Dengan perkembangan masyarakat, baik di bidang teknologi, ekonomi, maupun dunia usaha, maka muncullah perbuatan-perbuatan melawan hukum yang sifatnya ringan tetapi sangat membahayakan masyarakat umum (public welfare offences). Kejahatan dalam bentuk ini kadang-kadang tidak disertai dengan niat jahat sebagaimana halnya dengan kejahatan-kejahatan lain, seperti: pencurian, pembunuhan, dan sebagainya. Kejahatan ini kadangkala hanya berupa pelanggaran peraturan yang berdampak pada membahayakan masyarakat (regulatory offences), misalnya yang berkaitan dengan minuman keras, penggunaan obatobatan terlarang, pencemaran lingkungan, perlindungan konsumen, dan sebagainya. Clanville Williams (yang dikutip oleh RomliAtmasasmita) juga mengemukakan bahwa perbuatan pelanggaran terhadap peraturan umum adalah pelanggaran terhadap ketentuan yang mengatur mengenai pendidikan, penjualan, penguasaan, hubungan buruh-majikan, dan lalulintas. ${ }^{9}$

Dalam rangka mengatasi perkembangan kejahatan yang semakin kompleks tersebut nampaknya hukum pidana klasik yang menganut asas kesalahan sudah tidak mampu lagi. Oleh karena itu, perlu dilakukan

9 Atmasasmita, Romli, 2014, Bunga Rampai Kriminologi, Rajawali Pers, Jakarta, hlm.3435 . pembaharuan di bidang hukum pidana dengan mengakui bahwa asas kesalahan bukan lagi satu-satunya asas yang dapat dipakai untuk menentukan dipidana nya seseorang. Dalam hukum pidana modern pertanggungjawaban pidana juga dapat dikenakan kepada seseorang, meskipun orang tersebut tidak mempunyai kesalahan sama sekali.

Alasan utama untuk menerapkan pertanggungjawaban pidana tanpa kesalahan ituadalah demi perlindungan masyarakat, karena untuk delik-delik tertentu(sepertitindak pidana korporasi dan delik-delik tertentu lainnya diatas) sangat sulit membuktikan adanya unsur kesalahan. Ada tiga macam bentuk/ model system pertanggungjawaban pidana tanpa kesalahan, yaitu:

a) Pertanggungjawaban pidana mutlak (strict liability), yang unsur pokoknya adalah perbuatan (octusreus), bukan mensrea. Landasan penerapannya, antara lain:

1. Tidak berlaku umum terhadap semua jenis tindak pidana, tetapi sangat terbatas dan tertentu terutama mengenai kejahatan anti-social atau yang membahayakan social;

2. Perbuatan tersebut benar-benar melawan hukum (unlawful) yang sangat bertentangan dengan kehati-hatian yang diwajibkan hukum dan kepatutan;

3. Perbuatan tersebut dilarang keras oleh undang-undang karena dikategorikan sebagai 
aktivitas yang sangat potensial mengandung bahaya kepada kesehatan, keselamatan, dan moralik (a particular activity potential danger of public health, safety, or moral);

4. Perbuatan tersebut secara keseluruhan dilakukan dengan caratidakmelakukan pencegahan yang sangat wajar (unreasonable preausions). ${ }^{10}$

Dalam

perspektif

iusconstituendum, system pertanggungjawaban pidana mutlak juga sudah dirumuskan dalam Konsep KUHP Tahun 2014-2015, Pasal 32 ayat (3) yang menyebutkan:"Untuk tindak pidana tertentu, undang-undang dapat menentukan bahwa seseorang dapat dipidana semata-mata karena telah terpenuhinya unsur-unsur tindak pidana tersebut tanpa memperhatikan adanya kesalahan".

Secara teoretis, asas tanggung jawab mutlak (strict liability) telah diperkenalkan sejak pertengahan abad ke-19.Di Indonesia sendiri, pengetahuan mengenai asas strict liability tidakhanya terbatas dikalangan teorisasi atau ilmu hukum pidana. Sebab sesungguhnya asas tersebut telah diterapkan sejak lama dalam penegakan hukum, terutama dalam penegakan pelanggaran lalulintas jalan raya. ${ }^{11}$

10 Harahap, Yahya, 2007, Beberapa Tinjauan tentang Permasalahan Hukum, Citra Aditya Bakti, Bandung, hlm.37-38.

11 Arief, Barda Nawawi, 2013, Kapeta Selekta Hukum Pidana, PT. Citra Aditya Bakti, Bandung hlm.237. b) P e r t a ng u n g j a w a b a n pidana pengganti (vicarious liability), dikenal di Negaranegara Anglo Saxon, yakni "the legal responsibility of one person for wrongful acts of another". Pertanggungjawaban pidana pengganti adalah pertanggungjawaban seseorang, tanpa kesalahan pribadi, bertanggung jawab atas tindakan orang lain. Dalam perkara pidana, ada dua syarat penting yang harus dipenuhi untuk dapat menerapkan perbuatan pidana dengan pertanggungjawaban pribadi (vicarious liability), yaitu:

1. The must relationship between $X$ which is sufficient to justify the imposition of vicarious liability;

2. The criminal conduct commited by $Y$ must be referable in some particular way to relationship between $X$ and $Y .^{12}$

Disamping dua syarat tersebut diatas, terdapat dua prinsip yang harus dipenuhi dalam menerapkan vicarious liability, yaitu prinsip pendelegasian (the delegation principle) dan prinsip perbuatan buruh merupakan perbuatan majikan (the servant's act is the master's act in law). ${ }^{13}$

$\begin{array}{crr}\text { Latar } & \text { belakang } & \text { alasan } \\ \text { dicantumkan } & \text { nya } & \text { asas }\end{array}$

12 Flatcher, Marcus, 1990, A. Level Principle of English Law, IstEditon, HLT Publication, London, hlm.194.

13 Redmon, PWD, 1979, General Principle of English law, Ist Edition, Macdonald and Evan, London, hlm.232. 
pertanggungjawaban pengganti ini dalam Konsep KUHP Tahun 20142015, dalam penjelasan Pasal 32 ayat (2) menyebutkan:"Ketentuan ayat ini merupakan perkecualian dari asas tiada pidana tanpa kesalahan. Lahirnya pengecualian ini merupakan penghalusan dan pendalaman asas regulative dan yuridis moral, yaitu dalam hal-hal tertentu tanggungjawab seseorang dipandang patut diperluas sampai kepada tindakan bawahannya yang melakukan pekerjaan atau perbuatan untuknya atau dalam batas-batas perintahnya. Oleh karena itu, meskipun seseorang dalam kenyataannya tidak melakukan tindak pidana namun dalam rangka pertanggungjawaban pidana ia dipandang mempunyai kesalahan jika perbuatan orang lain yang berada dalamkedudukan yang sedemikian itu merupakan tindak pidana. Sebagai pengecualian, maka ketentuan ini penggunaannya harus dibatasi untuk kejadian-kejadian tertentu yang ditentukan secara tegas oleh undang-undang agar tidak digunakan secara sewenang-wenang. Asas pertanggungjawaban yang bersifat pengecualian ini dikenal sebagai"vicarious liability".

c) P e r t a ng ung j a w a a n tindak pidana korporasi, dikatakan bahwa korporasi bertanggungjawabatasperbuatan yangdilakukananggotanyadalam kaitan dengan ruang lingkup pekerjaannya. Tentu saja pidana yang dapat dijatuhkan kepada korporasi biasanya pidana denda atau berupa tindakan lain, seperti tindakan tata tertib atau tindakan administrasi.

Ada dua cara untuk dapat memidana korporasi, yaitu:

1. Korporasidapatdikenakanpidana berdasarkan asas vicarious

liability atas kejahatan yang dilakukan oleh pegawainya;

2. Korporasidapatdikenakanpidana berdasarkan teori identifikasi. Pengadilan mengakui tindakan dari anggota tertentu dari korporasi, selamatindakan ituberkaitan dengan urusan korporasi, dianggap sebagai tindakan dari korporasi itu sendiri. ${ }^{14}$

Teori identifikasi sebagaimana disebutkan diatas, adalah salah satu teori yang menjustifikasi pertanggungjawaban korporasi dalam hukum pidana. Teori ini menyebutkan bahwa"the act and state of the person are the act and state of mind of the corporation"(tindakan kehendak dari direktur adalah juga merupakan tindakan dan kehendak dari korporasi). Teori identifikasi membatasi pertanggungjawaban korporasi terhadap tindakan orang-orang yang mewakili korporasi, seperti dewan direksi, dan pejabat-pejabat puncak korporasi, sebagai penentu kebijakan.

Ada beberapa tolak ukur/dasar yang dapatdipergunakan sebagaialasan pembenar terhadap penyimpangan asas 14 Saego, Peter, 1989, Criminal law, Ist Edition, Sweet \$Mazwell, London, hlm.134-144. 
kesalahan dalam pertanggungjawaban pidana korporasi mempunyai relevansi untuk diterapkan di Indonesia, yaitu:

\section{a) Dasar Pembenar Teoretis}

Relevansi teoritis ini perlu dikemukakan dengan pertimbangan apakah keberlakuan suatu kaidah hukumtidak bertentangan dengan kecenderungan pemikiran secara global.Demikian juga harus dikaitkan dengan jalan pikiran ilmiah kalangan akademisi hukum, artinya apakah kaedah hukum yang baru diintrodusir itu dapat diterima atau ditolak oleh kalangan ilmuan hukum dengan berbagai alasan dan argumentasi yang dikemukakan.

Dicantumkannya penyimpangan terhadap asas kesalahan ini mendapat tanggapan pro dan kontra dikalangan para ahli hukum, seperti Schaffmesiter menganggap bahwa penyimpangan itu merupakan hal yang bertentangan dengan mensrea. Namun Barda Nawawi Arief, berpendapat bahwa pengecualian atau penyimpangan dari suatu asas jangan dilihat sematamata sebagai suatu pertentangan (contradiction), tetapi juga harus dilihat sebagaipelengkap (complement) dalam mewujudkan asas keseimbangan, yaitu keseimbangan antara kepentingan pribadi dengan kepentingan masyarakat, keseimbangan antara kedua kepentingan itulah oleh beliau dinamakan sebagai asas monodualistik. ${ }^{15}$

15 AriefBarda Nawawi, Op.Cit., hlm.112-113.
Pembenaran penyimpangan terhadap asas kesalahan dalam pertanggungjawaban pidana korporasi dapat dikaji atas dasar tujuan pidana dan pemidanaan yang bersifat integrative dalam rangka perlindungan social, yaitu: (1) pencegahan umum dan khusus; (2) perlindungan masyarakat; (3) memelihara solidaritas masyarakat; dan (4) pengimbalan atau pengimbangan.

\section{b) Dasar Pembenar Sosiologis}

Relevansi sosiologis ini dibutuhkan untuk menilai sejauhmana penyimpangan asas kesalahan dalam pertanggungjawaban pidana dapat diterima oleh masyarakat.Sehubungan dengan dengan hal tersebut, ada dua teori yang dikenal, yaitu teori pengakuan dan teori kekuasaan. Kedua teori tersebut digunakan oleh SoerjonoSoekanto dalam menilai keberlakuan hukum adat di Indonesia, juga akan dipergunakan dalam menilai sejauh mana penyimpangan asas kesalahan itu dapat diberlakukan atau tidak dalam masyarakat Indonesia. ${ }^{16}$

Menurut teori pengakuan, berlaku tidaknya suatu norma hukum itu ditentukan oleh sejauh mana masyarakat menerima dan mengakui sebagai norma yang ditaati. Secara ekstrem menurut pandangan teori pengakuan, suatu ketentuan hukum baru boleh dianggap sebagai hukum apabila ia diakui secara sah oleh masyarakat sendiri. Sedangkan

16 Soekanto, Soerjono, 1979, Masalah Kedudukan dan Peranan Hukum Adat, Akademika, Jakarta, hlm.5-6. 
menurut teori kekuasaan, berlaku tidaknya suatu norma itu dilihat sejauh mana norma itu diperlakukan oleh sesuatu kekuasaan tertentu.Secara ekstrem dapat dikatakan bahwa dalam pandangan teori kekuasaan, suatu norma hukum itu berlaku karena kekuasaannya sendiri yang bersifat perintah, terpisah dari pertimbangan ada tidaknya pengakuan dari masyarakat yang diaturnya.

Menurut hukum pidana adat, masalah pertanggungjawaban pidana tidak semata-mata menganut asas kesalahan sebagai unsure yang mutlak yang harus ada dalam suatu delik. Hukum pidana adat juga menuntut seseorang untuk bertanggungjawab walaupun tidak ada kesalahan sama sekali (seperti:strictliabiloity). Disamping itu, hukum adat juga memberikan kemungkinan untuk mempertanggungjawabkan orang lain atau persekutuannya atas delik yang telah dilakukannya oleh anggota persekutuan tersebut. Tindakan reaksi atau koreksi itu tidak hanya dapat dikenakan pada sipelaku, tetapi dapat juga dikenakan pada kerabat atau keluarganya atau mungkin juga dibebankan kepada masyarakat yang bersangkutan untuk mengembalikan keseimbangan yang terganggu (seperti: strict vicarious). ${ }^{17} \quad$ Berdasarkan hal tersebut, dapat dikatakan bahwa perkembangan pemikiran mengenaisubjek delik dalam hukum

17 Widnyana, I Made , 1993, Kapeta Selekta Hukum Pidana Adat, PT. Eresco , Bandung, hlm.19-27. pidana sekarang ini mempunyai relevansi secara sosiologis dengan masyarakat Indonesia.

\section{c) Dasar Pembenar Filosofis}

Keberlakuan secara teoretis dan sosiologis diatas, perlu ditelaah lebih jauh kesesuaian nya dengan alam pikiran hukum dan falsafah hukum nasional adalah Pancasila.Pancasila sebagai ideologi Negara menyatakan bahwa kelima sila yang merupakan prinsip dasar serta pedoman bagi bangsa Indonesia dan hidup kenegaraan nya.

Seandainya asas kesalahan tetap dipertahankan berarti kepentingan pelaku delik didahulukan, tetapi kepentingan umum dikorbankan. Sebaliknya, jika penyimpangan asas kesalahan ditetapkan pada semua perbuatan pidana, berarti kepentingan umum didahulukan dan kepentingan pelaku delik dikorbankan.Oleh karena itu diambil jalan tengah, yaitu penyimpanganasas kesalahan diterima, tetapi hanya terhadap perbuatan pidana tertentu yang mengatur kepentingan umum atau yang sifatnya ringan (regulatory offence, public welfare offence, mala prohibita). Apabila kebijakan seperti itu dijalankan, maka berarti salah satu prinsip dasar dari Pancasila, yakni adanya keseimbangan antara kepentingan umum dengan kepentingan pribadi (asas monodualistik) telah dijalankan. 


\section{SIMPULAN}

a. KUHP tidak mengatur korporasi sebagai subjek hukum yang dapat dipidana, karena masih menganut prinsip subjek hukum hanyalah manusia alamiah. Sedangkan beberapa peraturan perundang-undangan diluar KUHP telah mulai mengatur secara parsial dan tidak konsisten bahwa korporasi sebagai subjek hukum pidana serta masalah pertanggungjawaban pidananya.

b. Dalam perspektif iusconstituendum subjek tindak pidana korporasi dan pertanggungjawaban pidananya telah dirumuskan secara tegas dan terperinci dalam naskah rancangan KUHP 2014-2015, Pasal 162, Pasal 44 sampai dengan Pasal 49. Dengan demikian secara prinsip telah diterima korporasi sebagai subjekhukum dalam hukum pidana, sehingga korporasi dapat dituntut dan dijatuhi pidana.

\section{DAFTAR PUSTAKA}

\section{Buku}

Barda Nawawi Arief, 2013, Kapeta Selekta Hukum Pidana, PT. Citra Aditya Bakti, Bandung.

Hatrik Hamzah, 2015, Asas-Asas

Pertanggungjawaban Korporasi

Dalam Hukum PIdana Indonesia, Rajawali Perss, Jakarta.

I Dewa Made Suartha, 2015, Hukum

Pidana Korporasi Persfektif
Pertanggungjawaban Pidana dalam Kebijakan Hukum Pidana Indonesia, Setara Press, Malang. I Made Widnyana, 1993, Kapeta Selekta Hukum Pidana Adat, PT.Eresco, Bandung.

Yahya Harahap, 2007, Beberapa Tinjauan Tentang Permasalahan Hukum, PT. Citra Aditya Bakti, Bandung.

Marcus Flatecher, 1990, A Level Principle of English, Ist Edition, HLT Publication, London.

MardjonoReksodiputero, 1994,

Kemajuan Pembangunan

Ekonomi Dan Kejahatan,

Pusat Pelayanan Keadilan Dan

Pengabdian Hukum, Universitas Indonesia, Jakarta.

Muladi, 1995, Korban Kejahatan

Korporasi, Bahan Penataran

Nasional Hukum Pidana dan

Kriminologi, Fakultas Hukum UNDIP, 3-15 Desember.

RomliAtmasasmita, 2014, Bunga

Rampai Kriminologi, Edisi III, PT. Rajawali Perss, Jakarta.

Shofie, Yusuf, 2013, Pelaku Usaha dan

Tindak Pidana Korporasi, Chalia Indonesia, Jakarta.

Sutan Remy Sjahdeini, 2006, Pertanggungjawaban Pidana Korporasi, PT Grafiti Pers, Jakarta.

SoerjonoSoekanto, 1979, Masalah

Kedudukan dan Peranan Hukum Adat, Akademika, Jakarta.

PWD.Redmon, 1979, General Principle of English Law, Ist 
Edition, Macdonald and Evan, London.

Peter Saego, 1989, Griminal Law, Ist Edition, Sweet S. Mazwell, London.

\section{Perundang-undangan}

Kitab Undang-Undang Hukum Pidana.

Undang-Undang Nomor 8 Tahun 1981 Tentang Kitab Undang Undang Hukum Acara Pidana.

Undang-Undang Nomor 7 Tahun 1957 Tentang Tindak Pidana Ekonomi.

UU No.23 Tahun 1997 tentang Pengelolaan Lingkungan Hidup.

UU No.5 Tahun 1997 tentang Psikotropika.

UU No.22 Tahun 1997 tentang Narkotika.

UU No.31 Tahun 1999 jo UU No.20 Tahun 2001 tentang Pemberantasan Tindak Pidana Korupsi.

UU No.36 Tahun 1999 tentang Telekomunikasi.

UUNo.15 Tahun 2002 tentang Tindak Pidana Pencucian Uang.

PERPU No.1 Tahun 2002 jo UU No.2 Tahun 2002 jo UU No.15 dan 16 Tahun 2003 tentang Tindak Pidana Terorisme. 